\title{
ADULT-ONSET STILL'S DISEASE EVOLVING WITH MULTIPLE ORGAN FAILURE: CASE REPORT AND LITERATURE REVIEW
}

\author{
Rafael Chakr $^{1}$, José Miguel Dora ${ }^{2}$, Fernando Lopes Nogueira ${ }^{3}$, Renato Seligman ${ }^{4}$
}

\section{INTRODUCTION}

Adult-onset Still's disease (AOSD) is a disorder similar to systemic onset juvenile idiopathic arthritis (Still's disease), affecting young adults worldwide. ${ }^{1-2}$ Rarely, AOSD can be life-threatening. ${ }^{3-5}$ From Brazil, where recurrent forms are prevalent, ${ }^{6}$ we report on a case of AOSD presenting with multiple organ failure.

\section{CASE DESCRIPTION}

A 49-year-old white woman with a 3-month fever and weight loss history presented to our hospital. She had symmetric arthritis of hands, facial and thoracic skin rash, high morning fever, nausea, myalgia, and sore throat. The hemoglobin level was $11.4 \mathrm{mg} / \mathrm{dL}$, white blood cell count was $16900 / \mathrm{mm}^{3}$ (bands, $3600 / \mathrm{mm}^{3}$ ), platelet count was $386000 / \mu \mathrm{L}$, aspartate and alanine aminotransferases were 94 and $86 \mathrm{U} / \mathrm{L}$, respectively, and erythrocyte sedimentation rate (ESR) was $45 \mathrm{~mm} / \mathrm{h}$. Autoimmune and infective serological tests (eg, viral hepatitis tests, anti-immunodeficiency virus antibody, antinuclear antibody rheumatoid factor and mononuclesosis antibodies) were negative; urinalysis and chest X-ray were normal. Staphylococcus aureus was present in 1 of 5 samples of blood cultures, and oxacyllin plus gentamicin therapy was started, but a transesophageal echocardiogram showed no vegetations. Abdominal computed tomography revealed nothing but splenomegaly.

After an initial improvement, the high fever and skin rash returned, and cervical lymphadenopathy was detected. Lymph node, bone marrow, and rash cutaneous biopsies were performed. Multiple organ failure (cardiovascular, pulmonary, renal, and hematologic) motivated intensive care unit admission, where management of septic shock, including hydrocortisone, succeeded. Lymph node biopsy revealed

\footnotetext{
${ }^{1}$ Rheumathology - Hospital de Clínicas de Porto Alegre - RS/Brazil

${ }^{2}$ Endocrinology - Hospital de Clínicas de Porto Alegre - RS/Brazil

${ }^{3}$ Cardiology - Hospital de Clínicas de Porto Alegre - RS/Brazil

${ }^{4}$ Internal Medicine - Hospital de Clínicas de Porto Alegre - RS/Brazil

E-mail: chakr@terra.com.br
}

chronic inflammatory infiltrate. Cultures were negative. A bone marrow specimen showed diffuse hypercellularity. The tuberculin test reading was impaired due to rash. A high serum ferritin level (> $2000 \mathrm{ng} / \mathrm{mL}$ ) was detected, and cutaneous biopsy showed vacuolar interface dermatitis, intersticial mucinosis, and little superficial chronic inflammatory infiltrate, unspecific findings of autoimmune diseases. The patient gradually improved and was discharged asymptomatic from the hospital with oral prednisone after completing antibiotic treatment. In outpatient follow-up, slow tapering of prednisone is in course without evidence of recurrence.

\section{DISCUSSION}

Adult-onset Still's disease was first described by Bywaters in 1971. ${ }^{1}$ It is an uncommon disorder (incidence of 0.16 cases/ 100000 persons/year), presenting mostly with arthritis, spiking daily fever, a salmon-colored rash, lymphadenopathy, leukocytosis, and elevated ESR. ${ }^{2,7}$ High-sensitivity classification criteria have been proposed, since there is no single test to establish the diagnosis (Table 1) ${ }^{8-9}$ In Brazil, disease onset is around 30 years. ${ }^{6} 10$ Fever, arthritis, and skin rash are the most common clinical signs, and elevated ESR, leukocytosis, absent antinuclear antibody, and absent rheumatoid factor are the most frequent laboratory findings. ${ }^{6,10-11}$

Table 1 - Classification criteria for adult-onset Still's disease proposed by Yamaguchi et al

\begin{tabular}{ll}
\hline Major criteria & Minor criteria \\
\hline Temperature of $>39^{\circ} \mathrm{C}$ for $>1 \mathrm{wk}$ & Sore throat \\
Leukocytosis $>10000 / \mathrm{mm}^{3}$ & Lymph node enlargement \\
Typical rash & Splenomegaly \\
Arthralgias $>2 \mathrm{wk}$ & High transaminases \\
& Negative ANA, RF
\end{tabular}

After excluding infections, malignancies, and other rheumatic diseases, adult Still's should be considered if 5 criteria ( 2 of which being major ones) are met. $\mathrm{ANA}=$ antinuclear antibody; $\mathrm{RF}=$ rheumatoid factor

By the installation of multiple organ failure, the diagnosis had not yet been confirmed. Large spectrum antibiotics 
Table 2 - Previous case reports of adult-onset Still's disease evolving with organ failure

\begin{tabular}{lllllll}
\hline Gender / Age & Organ failure & Antibiotic use & $\begin{array}{l}\text { Years since first } \\
\text { symptoms }\end{array}$ & $\begin{array}{l}\text { Previous immuno- } \\
\text { suppressive therapy }\end{array}$ & Follow-up & Year / Country \\
\hline F / 49 & R; H; CV; P & Yes & 0 & No & OMT & 2007 / Brazil \\
M / 47 & H, C, P & Yes & 3 & Yes & Death & $2001 /$ France \\
F / 29 & H, CV, P & Yes & 20 & No & OMT & 1999 / USA \\
F / 23 & H, R, C, P & Yes & 2 & OMT & $1991 /$ Canada \\
\hline
\end{tabular}

$\mathrm{F}=$ female $\mathrm{M}=$ male; $\mathrm{OMT}=$ Outpatient maintenance therapy; $\mathrm{R}=$ renal $; \mathrm{H}=$ hematological $\mathrm{CV}=$ cardiovascular; $\mathrm{P}=$ pulmonary, $\mathrm{C}=$ central nervous system

were mandatory, since for diagnosis of AOSD, a fever not related to infection is always one criterion of inclusion. After innumerous negative cultures, steroid response, and the fulfilling of classification criteria (Table 1), the diagnosis could be established. Lack of hemophagocytosis and hypofibrinogenemia with elevated ESR allowed the exclusion of macrophage activation syndrome. ${ }^{12-13}$

Only 3 cases of AOSD evolving with shock and multi- ple organ failure have been reported (Table 2), and all of them had previous medical data facilitating early diagnosis. ${ }^{5-7}$ Treatment of severe cases requires glucocorticoids, sometimes immunosuppressants (eg, methotrexate), and biological agents (anti-tumor necrosis factor-alpha, antiinterleukin-1, anti-interleukin-6 agents, and most recently anti-CD20-expressing B-cell antibodies). ${ }^{13-14}$ Due to its rarity, prognosis of the severe onset form is still unknown. ${ }^{15}$

\section{REFERENCES}

1. Bywaters EG. Still's disease in the adult. Ann Rheum Dis. 1971;30:12133.

2. Ohta A, Yamaguchi M, Kaneoka H, Nagayoshi T, Hiida M. Adult Still's disease: review of 228 cases from the literature. J Rheumatol. 1987;14:1139-46.

3. Khraishi M, Fam AG. Treatment of fulminant adult Still's disease with intravenous pulse methylprednisolone therapy. J Rheumatol. 1991;18:1088-90.

4. Mejjad O. A shock associated with adult-onset Still's disease. Joint Bone Spine. 2001;68:76-8.

5. Iglesias J, Sathiraju S, Marik PE. Severe systemic inflammatory response syndrome with shock and ARDS resulting from Still's disease. Clinical response with high-dose pulse methylprednisolone therapy. Chest. 1999;115:1738-40.

6. Appenzeller S, Castro GR, Costallat LT, Samara AM, Bertolo MB. Adultonset Still disease in southeast Brazil. J Clin Rheumatol. 2005;11:7680.

7. Magadur-Joly G, Billaud E, Barrier JH, Pennec YL, Masson C, Renou $P$, et al. Epidemiology of adult Still's disease: estimate of the incidence by a retrospective study in west France. Ann Rheum Dis 1995;54:58790.

8. Yamaguchi M, Ohta A, Tsunematsu T, Kasukawa R, Mizushima Y, Kashiwagi H, et al. Preliminary criteria for classification of adult Still's disease. J Rheumatol. 1992;19:424-30.
9. Masson C, Le Loët X, Lioté F, Dubost JJ, Boissier MC, Perroux-Goumy $\mathrm{L}$, et al. Comparative study of 6 types of criteria in adult Still's disease. J Rheumatol. 1996;23:495-7.

10. Carvalho Filho AX, Guimarães SJ, Barros R, Fernandes MM, Nabuco R, Goldfarb M, et al. Adult-onset Still's disease: study of ten cases. Rev Bras Reumatol. 1998;38:169-74.

11. Jaime MAI, Baptista R, Azevedo MNL, Nentzinsky V, Kik AA, Sauaya DR, et al. Adult onset Still's disease: study on 25 cases. Rev Bras Reumatol. 1998;38:285-90.

12. Arlet JB, Le TH, Marinho A, Amoura Z, Wechsler B, Papo T, Piette JC. Reactive haemophagocytic syndrome in adult-onset Still's disease: a report of six patients and a review of the literature. Ann Rheum Dis. 2006;65:1596-601.

13. Efthimiou P, Georgy S. Pathogenesis and management of adult-onset Still's disease. Semin Arthritis Rheum. 2006;36:144-52.

14. Ahmadi-Simab K, Lamprecht P, Jankowiak C, Gross WL. Successful treatment of refractory adult onset Still's disease with rituximab. Ann Rheum Dis. 2006;65:1117-8.

15. Fraisse TC, Degraeve F, Riviere S, Le Quellec A, Bertolo MB. Evolution and prognosis of adult onset Still's disease. A monocentric study of 17 patients. Rev Med Interne. 2006;27:658-64. 